\title{
The Development of New Clinical Legal Education Courses at the Faculty of Law, Hasanuddin University, Makassar- Indonesia: Challenges and Prospects*
}

\author{
Maskun \\ Faculty of Law, Hasanuddin University \\ Jln. Perintis Kemerdekaan Km. 10, Tamalanrea, Makassar, South Sulawesi, 90245, Indonesia. \\ Tel./Fax:+62-411-587219 E-mail: maskunlawschool@yahoo.co.id \\ Submitted: Oct 6, 2015; Reviewed: Nov 12, 2015; Accepted: Nov 20, 2015
}

\begin{abstract}
Clinical subjects are a new model in Faculty of Law Hasanuddin University's curriculum. It currently is implementing four legal clinics: (1) a civil law clinic; (2) a criminal law clinic; (3) an anti-corruption law clinic; and (4) an environmental law clinic. All of these clinics have been adopted in FH-UNHAS's curriculum. This paper will focus on those subjects as new clinics and the students as new clinicians. It also discusses many challenges we face in managing the clinics and ensuring that all clinic students are able to engage in quality programming while working with our partners (local civil society organizations [CSOs] and formal justice institutions, such as District Courts and Provincial Prosecutor Offices).
\end{abstract}

Keywords: CLE; Challenges; Prospects

\section{INTRODUCTION}

The Faculty of Law, Hasanuddin University (FH UNHAS) was established in 1952 as one of UNHAS faculties. It has 8 (eight) departments right now, namely, civil law, criminal law, international law, constitutional law, administrative law, law and development, procedural law, and the basic law. ${ }^{1}$ It also provides $144-145$ credits to be applied by students in order to get their bachelor degree ( $\mathrm{SH}$ - for undergraduate). 135 credits

See: http://unhas.ac.id/law/?page_id=6 out of 145 are compulsory credits depending on the number of subjects and 10 credits are elective credits.

Its major competency basically is to provide students who have a good capacity in legal knowledge and skill. Both competencies are decided by Ministry Education and Culture through its Decree (namely Kepmendiknas No. 045/2002) to be fulfilled by all Faculty of Law (FH) in Indonesia. The decree indirectly has showed that every FH should consider to its students to have both 
competencies. It means that they have to explore and elaborate their curriculum or subjects to comply the competencies.

In terms of legal knowledge, the curriculum will provide theories, principles, and basic legal knowledge for the students in general. In the area of legal skill itself, the FH should provide them not only the skill of legal analysis but also the skill of legal practice. The skill actually is very important for the students when they are graduation and when they want to choose working in the area of practices, such as lawyers, attorneys, judges, government offices, corporate offices, and even in civil society organization (CSO), as well private firms. The question for the skill, has it applied in some subjects in $\mathrm{FH}$ in Indonesia, including FH UNHAS?

Expanding this question is needed to acknowledge whether it is applied or not. Pursuant to FH curriculum, there are some subjects potentially to apply legal skill (practice ready) in the framework of Clinical Legal Education (CLE) such as criminal procedural law, civil procedural law, islamic procedural law, procedural law of constitutional court, administrative procedural law, and legislative drafting. However, those subjects just provide non-experiential in achieving the goal of the subjects.

Based on the fact as mentioned, in 2012, CLE was initiated by the Asia Foundation in collaboration with the Faculty of Law at the University of Hasanuddin (FH UNHAS). Even though clinical subjects are a new model in FH UNHAS's curriculum, a similar, yet different, program exists at $\mathrm{FH}$ UNHAS under its Consultation and Legal
Aid Unit. FH UNHAS currently is implementing four legal clinics: (1) a civil law clinic, (2) a criminal law clinic, (3) an anticorruption law clinic, and (4) an environmental law clinic. All of these clinics have been adopted in FH-UNHAS's curriculum. To support the implementation of legal clinics, the FH UNHAS has also established partnerships with local civil society organizations (CSOs) and formal justice institutions, such as District Courts and Provincial Prosecutor Offices.

This paper will focus on the development of new clinical legal education courses and its challenge and prospect. As we know, FH UNHAS is still facing many challenges with regard to managing these relationships and ensuring that all clinic students are able to engage in quality programming while working with our partners. Apart from the success of incorporating clinical subjects in the faculty curriculum, we are facing some additional challenges. First, clinical courses are only elective subjects in our curriculum. This means that those subjects could be eliminated at any time and therefore law faculty lack the commitment to dedicate the needed time to rigorously implement the clinics. Second, there is a lack of well-trained clinic lecturers in our faculty, therefore we do not have faculty with strong organization skills, time management skills, interactive teach skills, and external partner supervising skills. Third, we lack the financial planning skills to properly budget for legal clinics, therefore putting their sustainability in jeopardy because the financial support of E2J has concluded and we must now figure out institutionally how to fund the clinics. 
ANALYSIS AND DISCUSSION

Clinical Legal Education at FH UNHAS:

\section{Concept and Design}

For many years (more than 60 years for FH UNHAS), FH in Indonesia almost tended to develop legal knowledge and legal skill only in the area of legal analysis. They believed that the skill legal analysis and substantive law were good enough for the students to enter labor market post-graduation. But, their hypothesis was wrong; the complexity of the labor market was not only put in the area of doctrinal approach, but also it was in the area of practice. In the area of practices, the FH's alumni found some difficulties to enter the labor market, especially when want to be a lawyer, an attorney, a judge, corporate office, and private firms. Consequences of lack of skill in practice, they had to study and work harder in order to be survived in their work.

This FH's fact in Indonesia as mentioned also took place in other countries. ${ }^{2}$ According to Margaret Martin Barry, ${ }^{3}$ law school introduces their students to the skill of legal analysis and to certain area of substantive law achieved their preparatory obligation. She states furthermore that the conveyance of doctrine through analysis of cases is the dominant approach to teaching and it has undeniable benefits. ${ }^{4}$ In other words, it can be said that the majority of law schools emerge their concern too much but their deliver too little to what the world labor market

2 Jeff Giddings, (2008), "Contemplating the Future of Clinical Legal Education", Griffith Law Review, 17 (1): pg. 2.

3 Margaret Martin Barry, (2012), "Practice Ready: Are We There Yet?", Boston College Journal of Law \& Social Justice, 32 (2), : 249.

4 Jeff Giddings, Op.Cit, pg.5. need for the school of law alumni. ${ }^{5}$

The phenomenon of emerging concern of law school especially in Indonesia has emphasized necessity of applying CLE in law school's curriculum. The curriculum must balance between legal knowledge and legal skill. In this case, the legal skill will increase diversity and complexity of the legal words that the alumni need in international intersections, the varied practice forums, economic sustainability, and recognition of bias within the law and its application. ${ }^{6}$ In terms of CLE's aim, both legal knowledge and skill substantively must fulfill some practice elements such as client interviewing and counseling, communication, fact investigation, drafting, negotiating, trial and pretrial practice, ethics, professionalism, cultural awareness, problem solving, and other practice skills. Those elements had previously been forgotten from the traditional law school curriculum especially in developing countries that overwhelmingly utilized either a lecture and/or seminar discussion format to teach substantive law. ${ }^{7}$

In FH UNHAS itself, CLE is new model of its curriculum. As mentioned before, CLE was introduced by the Asia Foundation collaboration with 8 (eight) universities in Indonesia. In some occasion when CLE has to be socialized to some lecturers, mostly professors and senior lecturers say that there is no difference between CLE model and FH

\footnotetext{
Phylliss Goldfarb, (2012), "Back to the Future of Clinical Legal Education", Boston College Journal of Law \& Social Justice, 32 (2): 281. See also Maisel, Peggy. (2006), "Expanding and Sustaining Clinical Legal Education in Developing Countries: What We Can Learn From South Africa", Fordham International Law Journal, 30(2): 375.

Margaret Martin Barry, Op.Cit, pg. 250.

Ibid.pg. 252.
} 
UNHAS existed model. They stipulate furthermore that some subjects as if criminal procedural law, civil procedural law, islamic procedural law, procedural law of constitutional court, administrative procedural law, and legislative drafting have applied CLE model in their teaching model. However, it is totally inaccurate.

Theoretically, CLE model requires 3 (three) basic components to be fulfilled. They are planning component, experiential component, and reflection. ${ }^{8}$ Those components must be showed clearly in teaching guideline that lecturer made, particularly for the experiential component. The planning component requires $30-35 \%$ of subject's value. It consists of learning legal theories, understanding a strategy in providing legal service and improving analytical skills on legal problems/issues. The experiential component will draw practice sides of the subject that consists of a practical skill and conduct other various practical activities, such as conducting a street law for public. This learning component is all about mastering a lawyering skill: client interviewing exercises, negotiation exercises and transaction exercises, legal writing and argument drafting programs. In the purpose subject value, it covers $60-65 \%$. The reflective component itself consists of self-evaluation skills, peerreview skills, student's ability to accept critiques and comments from the supervisor. It requires $5-10 \%$ for the subject value.

Those CLE's components as mentioned cannot be found in FH existed subjects fully. Therefore, to develop CLE in FH

\footnotetext{
8 Source: $h$ http://en.pendidikanhukumklinis.net/legalclinic/develop-clinical-legal-education-in-lawschool/.
}

UNHAS curriculum, it adopted a new subject of CLE as a pilot project to be implemented to other existed FH UNHAS subjects. It currently is implementing four legal clinics: (1) a civil law clinic, (2) a criminal law clinic, (3) an anti-corruption law clinic, and (4) an environmental law clinic. All of course these clinics have been adopted in FH-UNHAS's curriculum.

\section{The Development of CLE Model at FH UNHAS}

As we know, FH UNHAS has 4 (four) clinics. Both a civil law clinic and an anticorruption law clinic are in odd semester whereas a criminal law clinic and an environmental law clinic are in even semester. The number of students who enroll in those clinics are also various. The civil law and criminal law clinics are the most favorite clinics where around 75-100 students enroll both clinics in every semester while clinic of anti-corruption law is interested by $40-50$ students each semester and environmental law clinic is only enrolled by $10-15$ students.

The following table of the number of the clinical students will show how they are interested in those clinics. The reason why both civil law and criminal law clinics are interested by many students, it is because the students consider that both clinics are sustainability of criminal and civil procedural law.

Table 1. Number of Clinicians at FH UNHAS

\begin{tabular}{clccc}
\hline No & Name of Clinics & $\mathbf{2 0 1 2}$ & $\mathbf{2 0 1 3}$ & $\mathbf{2 0 1 4}$ \\
\hline 1 & A civil law clinic & 70 & 80 & 86 \\
2 & $\begin{array}{l}\text { A criminal law } \\
\text { clinic }\end{array}$ & 70 & 80 & 20 \\
& $\begin{array}{l}\text { An anti-corruption } \\
4\end{array}$ & 50 & 25 & 45 \\
4 & $\begin{array}{l}\text { law clinic } \\
\text { An environmental } \\
\text { law clinic }\end{array}$ & 12 & 10 & 20 \\
\hline
\end{tabular}


However, no all the students who enroll the clinics would conduct experiential component. There is policy in the CLE model at FH UNHAS to just take 5-14 students to do the experiential component. Therefore, to deal with this fact, the clinical lecturers conduct selection to get the number of the clinicians as required.

Tabel 2. Number of Clinicians who follow the experiential component at FH UNHAS

\begin{tabular}{|c|c|c|c|c|}
\hline No & Name of Clinics & 2012 & 2013 & 2014 \\
\hline 1 & A civil law clinic & 14 & 14 & 15 \\
\hline 2 & A criminal law clinic & 12 & 10 & 20 \\
\hline 3 & $\begin{array}{l}\text { An anti-corruption law } \\
\text { clinic }\end{array}$ & 8 & 4 & 18 \\
\hline 4 & $\begin{array}{l}\text { An environmental law } \\
\text { clinic }\end{array}$ & 12 & 10 & 20 \\
\hline
\end{tabular}

Even the clinical academics hasd done selection to determine which students are eligible to follow all components of clinic, the truth also showed that no all the clinicians could finish the clinics properly, especially for the anti-corruption law clinic in 2013.

One of the important notes from the FH UNHAS clinics is that those clinics are taught in the third-year of law school. It means all students who enroll the clinic subjects are in the semester 6 or 7 . This is actually referred to design of CLE in the E2J project. The reason why all clinic subjects must be scheduled in the third-year of law school is because the students are expected and believed that they have had a good enough of substantive of law theoretically. They need some legal theories and basic legal knowledge before they get involved in CLE. In other words, it can be said that it is impossible to the students to do practice if they do not have basic legal knowledge standard. They cannot do a great analysis, legal writing, and other skill they have to have if they have in the first-year of school of law.

Based on the FH UNHAS experience, the similarity between some procedural law subjects and the FH UNHAS's clinic subjects are that they are offered in the third-year of law school. Indeed, they have difference approach when they are teaching as mentioned in the component of CLE. Therefore, to develop the FH UNHAS's curriculum, it would be better if all procedural subjects such as criminal procedural law, civil procedural law, islamic procedural law, procedural law of constitutional court, administrative procedural law, and legislative drafting are designed to fulfill the standard of CLE as the FH UNHAS's experience.

The idea of developing those subjects to cater CLE's standard is because those subjects generally are compulsory subjects. It means that these subjects shall be enrolled by all FH UNHAS's students in the thirdyear of law school or during they are law students. It will also easy for the FH UNHAS to organize those subjects not only into its curriculum but also in its organization structurally. In terms of its organization, the idea of it can be seen in this chart below.

Understanding the chart above, it can be seen that CLE can be addressed not only to 4 clinics but also can be developed to other subjects particular procedural law subjects. Indeed, amongst those subjects have their own challenge and prospects. But, in the context CLE, those developed subjects (procedural law) will help law students to prepare themselves to be lawyer (practices). Therefore, it is pivotal to FH UNHAS to build partnership with other institution to 


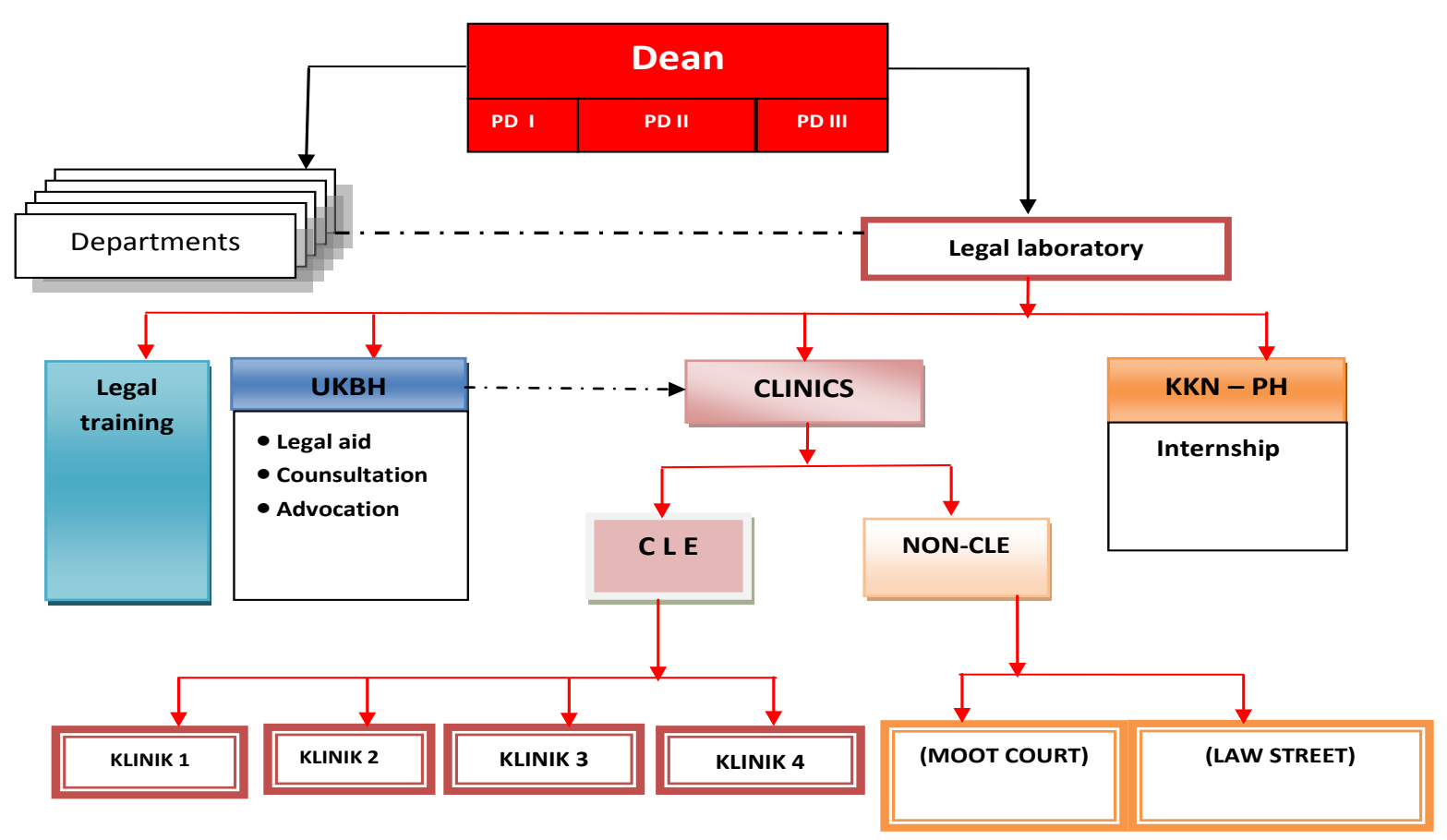

Source: Legal Laboratory of FH UNHAS (2014)

support the implementation of CLE. Based on the experience right now, the FH UNHAS has established partnerships with local civil society organizations (CSOs) and formal justice institutions, such as District Courts and Provincial Prosecutor Offices to support its clinics since 2012.

The more your create CLE, the more you need partnership. Why partnership plays important role to implement CLE. It is because the component of experiential must be complied around $60-65 \%$ out of $100 \%$ of the credits of the subject. It means that in the process of developing those subjects, the FH UNHAS partner must be got involved to formulate the teaching material and syllabi for the subjects. Based on the experience of a criminal law clinic, the partnership of the clinic - called Legislative Monitoring Committee (KOPEL Indonesia), collaborate with the clinic lecturers to prepare the teaching material for the students, including the mark of the subject in the end of lecture. In an envi- ronmental law clinic, the clinic lecturers and together with the partner - called Sea Conservation Foundation - YKL) build teaching materials and syllabi. It can be found in the website of UNHAS -learning management system of UNHAS.

One of the achievements of $\mathrm{FH}$ UNHAS clinic is some ex-clinicians now are working to the partner particular to CSO. 2 (two) ex-clinicians of the environmental law clinic are working at YKL and 2 (two) ex-clinicians of the criminal law clinic are working at Legal Aid Unit for Women and Children (LBH APIK Makassar). In terms of formal justice institutions, we have no data because the institutions have not accepted their civil servants officially yet since 3 (three) years ago.

\section{Challenging and Prospecting of CLE at FH UNHAS}

The development of new clinical legal education courses has its challenge and pros- 
pect. As we know, FH UNHAS is still facing many challenges with regard to managing these relationships and ensuring that all clinic students are able to engage in quality programming while working with our partners. Apart from the success of incorporating clinical subjects in the faculty curriculum, we are facing some additional challenges.

\section{Clinical courses are only elective subjects in our curriculum}

The most important thing related to the curriculum basically is the necessity of law school to respond the labor market. For this condition, the question will arise how will law school (FH UNHAS for example) respond to renew challenge of the labor market? How the law schools try to reform its curriculum especially in national level? How the law schools' commitments and policy to tap this condition?

Discussing those questions actually is difficult. To respond the labor market means we have to consider all elements related to CLE. Reformation of the law school curriculum must be set up carefully. As we know, in Indonesia, the curriculum of FH is separated into national subjects, university subjects, department subjects - three kinds of subjects - are compulsory (135 credits), and elective subjects for 10 credits.

Based on the FH UNHAS' experience, the four FH UNHAS clinics are an elective subject in its curriculum. They were created at that time when the FH UNHAS's curriculum has been revised and it was impossible to re-revise. Therefore, the solution for that condition was just to put them as an elective subject. Consequence of it, they could be eliminated at any time. In other subjects furthermore (excluded the four clinics), those subjects are not well-integrated as CLE components. Therefore, one of the solutions is to increase the status of the CLE elective subjects to be compulsory or to maximize some procedural law subjects - compulsory - to fill their syllabi and teaching materials to be standardized as CLE.

It is realized actually by the law school academics that the necessity of CLE nowadays is really needed. It is indispensable. The CLE in law schools in the world globe begin to proliferate. In Australia for example, most of its universities - called the New South Wales University, Deakin University, Australian National University, Bond, University, Macquire University, Queensland University, and the Sydney University - have grown their interest to CLE. ${ }^{9}$ The proliferation of the law school is also consistent with the public interest. Another example can be found in some Japan and Malaysia universities.

\section{There is a lack of well-trained clinic lectur- ers in our faculty}

As a new model of CLE, the four clinics are taught by limited-clinical academics. Each clinic is supervised by 3 (three) clinical academics based on their background on that clinics. However, it is realized that the CLE is different to other FH UNHAS's subjects. It has its own characteristic to be taught. Therefore, the clinical lecturers actually need specific training related to CLE. Even though, they have been supervised to the lecturers that the E2J provided in the pro-

Jeff Giddings, Op.Cit. pg.3 
ject, they have still no experiences to handle the CLE classes as mentioned and explained prior. We have to have faculty with strong organization skills, time management skills, interactive teach skills, and external partner supervising skills.

Theoretically, well-trained clinic lecturers are considered a hallmark of CLE. It is because the practice based on CLE components has potential to offer very rich learning environment. ${ }^{10}$ If the lecturers do not have capability to teach or to dilute the CLE in appropriate ways, the benefits of the rich environment may be lost.

In the frame of development of CLE, the FH UNHAS clinical law lecturers have to be well-trained in order to manage the CLE classes. The ability to supervise the CLE must be had not only to limited lecturers, but also to all the FH UNHAS lecturers. They have the same possibility to teach and supervise the CLE depending on the subjects. The lecturers shall have capacity to persuade the students to take control over their learning. This is self-assessment of the FH UNHAS in organizing CLE during the last 2 (two) years.

We lack the financial planning skills to properly budget for legal clinics.

In the first year of the organizing of the CLE, the clinics financial were full supported by the E2J because they are a part of the E2J project. However, in the second year, they have to be managed by the FH UNHAS itself. Is it any influence of organizing the CLE as if in the first year?
To answer that question, it must be recognized that financial matter is an element pivotal to keep these subjects exist. Even though the influence does not show clearly, but the fact in managing the CLE class from the lecturers indicate that the lecturers are lack of motivation and they found some obstacles particular for the financial matter in experiential components. This condition of course, putting the sustainability of the CLE in jeopardy because the financial support of E2J has concluded and we must now figure out institutionally how to fund the clinics.

As we know, institutional fund of the FH UNHAS has to be calculated in the end of the year and it will be used for the next January to December at the following year. It is therefore that financial planning skill of the FH especially the Dean Deputy II, someone who is responsible in the FH UNHAS's financial matter, must cover and figure out it to the FH UNHAS fund. The financial planning is an effective way to keep the CLE exists in each semester either for the four clinics or the new CLE as though some procedural law subjects.

\section{CONCLUSION}

The development of new model clinics at FH UNHAS can be embodied. It has chance potentially to be developed. Some procedural law subjects - compulsory subjects have opportunity to be designed to follow the CLE components. Indeed, there is some challenging to do it such as well-trained clinic academics, partnership, and the financial planning. If they can be dealt with, the future of CLE at FH UNHAS will brighten. 


\section{BIBLIOGRAPHY}

Giddings, Jeff. (2008), "Contemplating the Future of Clinical Legal Education", Griffith Law Review, 17(1): 2.

Goldfarb, Phyllis. (2012), "Back to the Future of Clinical Legal Education", Boston College Journal of Law \& Social Justice, 32(2): 281.

Maisel, Peggy. (2006), "Expanding and Sustaining Clinical Legal Education in Developing Countries: What We Can Learn From South Africa", Fordham International Law Journal, 30 (2): 375.
Martin Barry, Margaret. (2012), “ Practice Ready: Are We There Yet?", Boston College Journal of Law \& Social Justice, 32(2): 249.

\section{Other sources:}

Hasanuddin University's Rector Decree, No. 56/H4/P/2011.

Hasanuddin University's Website at: http:// unhas.ac.id/law/?page_id $=6$

Pendidikan Hukum Klinis. Available online at: http://en.pendidikanhukumklinis. net/legal-clinic/develop-clinical-legaleducation-in-law-school/ 